\title{
Fractions of Selaginella convoluta (Arn.) Spring (Selaginellaceae) attenuate the nociceptive behavior events in mice
}

\author{
L. A. R. Oliveira-Macêdo ${ }^{a}$ (D) A. G. M. Pacheco ${ }^{a}$ (D), S. R. G. Lima-Saraiva ${ }^{a}$ (D), J. C. Silva ${ }^{a}$ (iD, \\ R. G. Oliveira-Júnior ${ }^{a}$ (D), G. R. Souza ${ }^{a}$ (D), E. M. Lavor $^{a}$ (D), M. G. Silva ${ }^{a}$ (D), J. N. S. Ferro ${ }^{b}$ (D), \\ E. Barreto ${ }^{b}$ (D), V. R. Oliveira ${ }^{c}$ (D) and J. R. G. S. Almeida ${ }^{a *}$ (D)
}

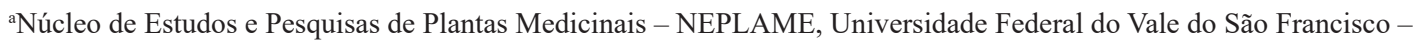
UNIVASF, CEP 56304-205, Petrolina, PE, Brasil

bLaboratório de Biologia Celular, Universidade Federal de Alagoas - UFAL, CEP 57072-970, Maceió, AL, Brasil

'Empresa Brasileira de Pesquisa Agropecuária - EMBRAPA, CEP 56302-970, Petrolina, PE, Brasil

*e-mail: jackson.guedes@univasf.edu.br

Received: January 3, 2018 - Accepted: June 4, 2018 - Distributed: February 28, 2020

(With 10 figures)

\begin{abstract}
Selaginella convoluta (Arn.) Spring is a species popularly known as "jericó", and used in folk medicine as analgesic and anti-inflammatory. This study aimed to investigate in mice the antinociceptive and anti-inflammatory activities of the hexane (Sc-Hex) and chloroform $\left(\mathrm{Sc}_{-} \mathrm{CHCl}_{3}\right)$ fractions $(100,200$ and $400 \mathrm{mg} / \mathrm{kg}$ ) obtained by partition of crude ethanol extract from $S$. convoluta. The preliminary phytochemical analysis of the fractions was performed. Antinociceptive activity was evaluated by writhing, formalin and hot-plate tests. Anti-inflammatory activity was evaluated using carrageenan-induced pleurisy. The rota-rod test was used to evaluate motor coordination. Preliminary phytochemical screening showed that the $\mathrm{Sc}-\mathrm{Hex}$ and the $\mathrm{Sc}-\mathrm{CHCl}_{3}$ were positive for the presence of flavonoids, anthracene derivatives, quinones, triterpenes and steroids. Inhibition of writhing was observed for fractions tested. The Sc-Hex at all doses tested was effective in reducing the nociceptive behavior produced by formalin only in the second phase. However, the $\mathrm{Sc}_{-} \mathrm{CHCl}_{3}$ decreased the paw licking time in the first and second phases. In the hot plate no significant effect was observed for any fraction. In the rota-rod test, treated mice did not demonstrate any significant motor performance changes. In the carrageenan-induced pleurisy, $\mathrm{Sc}_{-} \mathrm{CHCl}_{3}(200 \mathrm{mg} / \mathrm{kg})$ reduced cell migration to the pleural cavity. These results reveal the antinociceptive properties of $S$. convoluta, which support, in part, its traditional use, since the fractions did not presented significant activity in the inflammatory response profile. We further verify that this antinociceptive effect could be by activation of nociceptive peripheral pathway.
\end{abstract}

Keywords: Selaginella convoluta, Selaginellaceae, inflammation, nociception.

\section{Frações de Selaginella convoluta (Arn.) Spring (Selaginellaceae) atenuam a resposta nociceptiva em camundongos}

\begin{abstract}
Resumo
Selaginella convoluta é uma espécie popularmente conhecida como "jericó", e usada na medicina popular como analgésica e anti-inflamatória. Este estudo teve como objetivo investigar em camundongos as atividades antinociceptiva e anti-inflamatória das frações hexânica (Sc-Hex) e clorofórmica $\left(\mathrm{Sc}_{-} \mathrm{CHCl}_{3}\right)(100,200$ e $400 \mathrm{mg} / \mathrm{kg})$ obtidas por partição do extrato etanólico bruto de S. convoluta. A análise fitoquímica preliminar das frações foi realizada. A atividade antinociceptiva foi avaliada pelos testes de contorções abdominais, formalina e placa quente. A atividade anti-inflamatória foi avaliada usando pleurisia induzida por carragenina. $\mathrm{O}$ teste do rota-rod foi utilizado para avaliar a coordenação motora. A triagem fitoquímica preliminar mostrou que $\mathrm{Sc}-\mathrm{Hex}$ e $\mathrm{Sc}-\mathrm{CHCl}_{3}$ apresentaram reação positiva para a presença de flavonoides, derivados antracênicos, quinonas, triterpenos e esteroides. A inibição das contorções foi observada para as frações testadas. Sc-Hex em todas as doses testadas foi efetivo na redução do comportamento nociceptivo produzido pela formalina somente na segunda fase. No entanto, $\mathrm{Sc}-\mathrm{CHCl}_{3}$ diminuiu o tempo de lambida da pata na primeira e segunda fases. Na placa quente, nenhum efeito significativo foi observado para qualquer fração. No teste do rota-rod os camundongos tratados não demonstraram mudanças significativas na coordenação motora. $\mathrm{Na}$ pleurisia induzida por carragenina, $\mathrm{Sc}-\mathrm{CHCl}_{3}(200 \mathrm{mg} / \mathrm{kg})$ reduziu a migração celular para a cavidade pleural. Estes resultados revelam a propriedade antinociceptiva de $S$. convoluta, justificando, em parte, seu uso tradicional, uma vez que os extratos não apresentaram atividade significativa no perfil de resposta inflamatória. Verificamos ainda que esse efeito antinociceptivo mostrou-se ligado à ativação da via periférica nociceptiva.
\end{abstract}

Palavras-chave: Selaginella convoluta, Selaginellaceae, inflamação, nocicepção. 


\section{Introduction}

The pain and inflammation are a body defense reaction, in order to eliminate or limit the spread of injurious organisms, toxic chemical substances, and physical injuries from living mammalian tissues (Nahar et al., 2013; Sobota et al., 2000). Narcotic drugs, non-steroidal anti-inflammatory drugs (NSAIDs), steroidal and immunosuppressant drugs have been usually used in the relief of pain and inflammatory diseases by the people of the world for a long time (Lima-Saraiva et al., 2012). Furthermore, these drugs may have various and severe adverse side effects, such as gastric lesions caused by NSAIDs, tolerance and dependence induced by opiates, use of these drugs as anti-inflammatory and analgesic agents have not been successful in all cases (Carvalho et al., 2010; Menichini et al., 2009; Adedapo et al., 2008).

Medicinal plants have been used since ancient times as medicines for the treatment of diseases and still play a key role in world health to be potential source of drugs (Basso et al., 2005; Newman and Cragg, 2016; Jeelani et al., 2017). According to Kumara (2001), plant based drugs in traditional medicine are being paid much attention because of their minimal side effects, cheapness and also the fact that $80 \%$ of the world population still rely on them (Kumara, 2001). The chemical diversity of plants has made them one of the main sources for the isolation of bioactive organic compounds (Basso et al., 2005). Brazil is privileged because it ranks first among the richest countries in biodiversity in the world, accounting for $22 \%$ of the higher plant species on the planet (Rates, 2001).

The family Selaginellaceae Willk. is a distinctive family including the single genus Selaginella which is a nearly worldwide genus of about 700 species (Tryon and Tryon, 1982) to 750 species (Judd et al., 1999), with about 270 of them in America. Members of the Selaginellaceae occurs mostly terrestrial, herbaceous and perennial plants. Vary greatly in size, some small species have stems about $3 \mathrm{~cm}$ long, while larger ones have stems $50 \mathrm{~cm}$ to approximately $1 \mathrm{~m}$ long, under $2 \mathrm{~cm}$ tall (Judd et al., 1999).

Pharmacological and phytochemical studies on genus Selaginella led to identification of numerous bioactive molecules, including alkaloids, phenols (flavonoids, tannins, saponins), and terpenoids (triterpenes and steroids) (Almeida et al., 2013; Chikmawati et al., 2008), with broad biological activities, including antivirus, antifungal, antibacterial, cytotoxic, anticancer, antioxidant, antiplasmodial, leishmanicidal and anti-inflammatory properties (Lin et al., 1999; Jung et al., 2006; Lee et al., 2009a, b; Chen et al., 2005; Silva et al., 1995; Woo et al., 2006; Subramoniam et al., 2005; Pandey et al., 1993; Kunert et al., 2008; Kim et al., 1998; Gambhir et al., 1987).

Selaginella convoluta is a medicinal plant found in Northeastern Brazil commonly known as "jericó", "mão-de-sapo" and "mão-fechada" and it is used in folk medicine as antidepressant (Santos et al., 1994; Giorgetti et al., 2007), aphrodisiac, diuretic, against amenorrhea (Agra et al., 2007), cough, bleeding, increases female fertility (Albuquerque et al., 2007) as well as analgesic and anti-inflammatory (Almeida et al., 2005).

Previous study carried out by our research group demonstrated the antinociceptive effect of ethanolic extract in mice (Sa et al., 2012). In this way, the present work aimed to investigate the antinociceptive and anti-inflammatory effects of the fractions obtained by partition of the crude ethanol extract of $S$. convoluta in experimental models in mice.

\section{Material and Methods}

\subsection{Plant material}

Selaginella convoluta was collected in the city of Petrolina (Coordinates: S 0903'54”; W 40¹9'12') State of Pernambuco, Brazil, in March of 2012. A sample was identified by Viseldo Ribeiro de Oliveira, a researcher from Embrapa Semiárido. A voucher specimen (19203) was deposited at the Herbarium Vale do São Francisco (HVASF) of the Federal University of San Francisco Valley (UNIVASF).

\subsection{Preparation of plant extracts}

The dried and pulverized plant (1935 g) was macerated with ethanol $95 \%$ at room temperature for $72 \mathrm{~h}$. The extractive solution was filtered and concentrated under reduced pressure in a rotatory evaporator at $50{ }^{\circ} \mathrm{C}$, producing $146.55 \mathrm{~g}$ of crude ethanol extract (Sc-EEB). The Sc-EEB was suspended in a mixture of methanol and water $(3: 7)$ and extracted successively with hexane and chloroform in ascending order of polarity to obtain the fractios Sc-Hex $(21.26 \mathrm{~g})$ and $\mathrm{Sc}-\mathrm{CHCl}_{3}(15.14 \mathrm{~g})$, respectively.

\subsection{Phytochemical analysis}

The preliminary phytochemical screening, in order to establish the possible chemical nature of the compounds, was carried out with the fractions obtained by partitioning the Sc-EEB. The tests were performed according to the methodology described by Wagner and Bladt (1996) seeking to highlight the main groups of secondary metabolism.

\subsection{Animals}

Male adult albino Swiss mice (25-35 g) were used in this study. The animals were randomly housed in appropriate cages at $22 \pm 2{ }^{\circ} \mathrm{C}$ on a $12 \mathrm{~h} \mathrm{light/dark} \mathrm{cycle} \mathrm{with} \mathrm{free}$ access to food and water. They were used in groups of six animals each, according to the experiments realized. Experiments were performed during the light phase of the cycle. Treatment doses $(100,200$ and $400 \mathrm{mg} / \mathrm{kg}$ ) were chosen based on a previous study (Sá et al., 2012). All tests were carried out by the same visual observer. Experimental protocols and procedures were approved by the Universidade Federal do Vale do São Francisco Animal Care and Use Committee by number 0003/17072012.

\subsection{Pharmacological tests}

\subsubsection{Acetic acid-induced writhing test}

This test was done using the method described by Koster et al. (1959). Mice (25-35 g) were divided into nine groups. Acetic acid $(0.9 \% \mathrm{v} / \mathrm{v})$ was administered i.p. in a 
volume of $0.1 \mathrm{~mL} / 10 \mathrm{~g}$. Vehicle (saline), morphine (MOR, $10 \mathrm{mg} / \mathrm{kg}$ ), Indomethacin (INDO, $20 \mathrm{mg} / \mathrm{kg}$ ) and fractions $(100,200$ and $400 \mathrm{mg} / \mathrm{kg}$ ), were administered i.p. $30 \mathrm{~min}$ before acetic acid injection. The number of abdominal constrictions produced in each group for the succeeding 10 min was counted and compared to the response in the control group. Antinociceptive activity was calculated as the percentage inhibition of abdominal constriction.

\subsubsection{Formalin test}

The method used was similar to the described by Hunskaar and Hole (1987) and Viana et al. (1998). Twenty microliters of $2.5 \%$ formalin (in $0.9 \%$ saline, subplantar) was injected subcutaneously into the right hind paw of mice. The time (in seconds) spent in licking and biting responses of the injected paw was taken as an indicator of pain response. Responses were measured for $5 \mathrm{~min}$ after formalin injection (first phase, neurogenic) and 15-30 min after formalin injection (second phase, inflammatory). Vehicle (saline), morphine (MOR, $10 \mathrm{mg} / \mathrm{kg}$ ), acetylsalicylic acid (ASA, $150 \mathrm{mg} / \mathrm{kg}$ ) and fractions $(100,200$ and $400 \mathrm{mg} / \mathrm{kg}$ ), were administered i.p. $60 \mathrm{~min}$ before formalin injection. Mice were observed in the chambers with a mirror mounted on three sides to allow view of the paws. Antinociceptive activity was calculated as the percentage inhibition of licking time.

\subsubsection{Hot plate test}

Mice were divided into eight groups. Mice were pre-selected on the hot plate at $55 \pm 0.5^{\circ} \mathrm{C}$. Licks on the rear paws were the parameters of observation. Animals showing a reaction time (latency for licking the hind feet or jumping) greater than $20 \mathrm{~s}$ were discarded. The animals were then treated with vehicle (saline, $0.1 \mathrm{~mL} / 10 \mathrm{~g}$ ), morphine (MOR, $10 \mathrm{mg} / \mathrm{kg}$ ) and fractions $(100,200$ and $400 \mathrm{mg} / \mathrm{kg}$ ) via i.p. Latency time (in seconds) for each mice was determined on the hot plate during the maximum period of $20 \mathrm{~s}$, at intervals of 30, 60, 90 and $120 \mathrm{~min}$ after the administration of the treatment (Almeida et al., 2011).

\subsubsection{Carrageenan-induced pleurisy}

The animals ( $\mathrm{n}=6$ in each group) were pre-treated by intraperitoneal route (i.p.) with fractions $(100,200$ and $400 \mathrm{mg} / \mathrm{kg}$ ) $30 \mathrm{~min}$ prior to the induction of pleurisy. Pleurisy was induced by the intrapleural injection (i.t.) of $100 \mu \mathrm{L}$ of a $1 \%$ (v/v) carrageenan solution. A specially adapted $13 \times 5$ syringe was introduced into the right side of the thoracic cavity of mice to inject the carrageenan solution, and an equal volume of sterile saline was injected into the controls. At $4 \mathrm{~h}$ after the i.t. injection, the animals were sacrificed in a $\mathrm{CO}_{2}$ gas chamber and the thoracic cavity was opened and washed with $1 \mathrm{~mL}$ PBS containing EDTA $(10 \mathrm{mM})$. These pleural washes were recovered and their volume measured. Pleural wash samples were diluted in Turk fluid ( $2 \%$ acetic acid) for total leukocyte counts using Neubauer chambers. Indomethacin was used as reference drug. Thus, parallel group of animals was pre-treated (30 min before pleurisy induction) with indomethacin $(10 \mathrm{mg} / \mathrm{kg}$, i.p.) and $4 \mathrm{~h}$ later the same inflammatory parameters were evaluated (Farias et al., 2011).

\subsubsection{Measurement of total protein content}

The fluids recovered from the pleural cavity of the animals treated with the extracts Sc-Hex and $\mathrm{Sc}-\mathrm{CHCl}_{3}$ at 100,200 and $400 \mathrm{mg} / \mathrm{kg}$ were centrifuged for $10 \mathrm{~min}$ at $1.500 \times \mathrm{g}$, and the total protein content was quantified in the supernatant, at $640 \mathrm{~nm}$, using the Folin-Lowry technique (Stauffer, 1975).

\subsubsection{Motor coordination test (rota-rod test)}

A rota-rod treadmill device (Insight, Brazil) was used for the evaluation of motor coordination. Initially, $24 \mathrm{~h}$ before the test, mice capable of remaining on the rota-rod apparatus longer than $180 \mathrm{~s}(7 \mathrm{rpm})$ were selected. Thirty minutes after the administration of fractions (100, 200 and $400 \mathrm{mg} / \mathrm{kg}$, i.p.), vehicle (saline, $0.1 \mathrm{~mL} / 10 \mathrm{~g}$ ); control group) or diazepam $(2.5 \mathrm{mg} / \mathrm{kg}$, i.p.), each animal was tested on the rota-rod apparatus at $30 \mathrm{~min}, 1$ and $2 \mathrm{~h}$ post-treatment, and the time(s) the mice were able to remain on top of the bar was (were) recorded for up to $180 \mathrm{~s}$.

\subsection{Statistical analysis}

The data were expressed as mean \pm S.E.M. and the statistical significance were determined using an analysis of variance (ANOVA) followed by Dunnett's test. Values were considered significantly different at $p<0.05$. All analysis was performed using by GraphPad Prism 5.0 program.

\section{Results}

Preliminary phytochemical screening showed that the $\mathrm{Sc}-\mathrm{Hex}$ and the $\mathrm{Sc}-\mathrm{CHCl}_{3}$ were positive for the presence of flavonoids, anthracene derivatives, quinones, triterpenes and steroids.

The intraperitoneal administration of Sc-Hex $(100,200$ and $400 \mathrm{mg} / \mathrm{kg})$ showed dose-dependent antinociceptive effect and decreased significantly $(p<0.05)$ the number of writhing movements induced by the i.p. administration of the acetic acid compared with the control group. The percentages of inhibition were 64.93, 77.91 and $99.33 \%$, respectively (Figure 1). The Sc- $\mathrm{CHCl}_{3}$ produced inhibition of the abdominal writhing response by $90.16,90.16$ and $95.92 \%$ (Figure 2). Indomethacin caused a 90.92 and $88.53 \%$ reduction in writhing movements for animals treated with Sc-Hex and $\mathrm{Sc}-\mathrm{CHCl}_{3}$, respectively. Morphine abolished all of the nociceptive responses in all treated groups.

The results of the formalin test are shown in Figure 3 and Figure 4. Sc- $\mathrm{CHCl}_{3}$ showed a significant antinociceptive effect to inhibit the licking time in both phases (neurogenic and inflammatory pain) of the test, but the result was most significative in the second phase. $\mathrm{Sc}-\mathrm{CHCl}_{3}(100 \mathrm{mg} / \mathrm{kg}$, i.p. $)$ decreased by $35.46 \%$, the paw licking time in the first phase, as well as 82.06, 74.96 and $92.77 \%$, respectively, in the second phase of the formalin test. However, the Sc-Hex decreased the paw licking time only the second phase by $64.51,67.80$ and $73.90 \%$. 


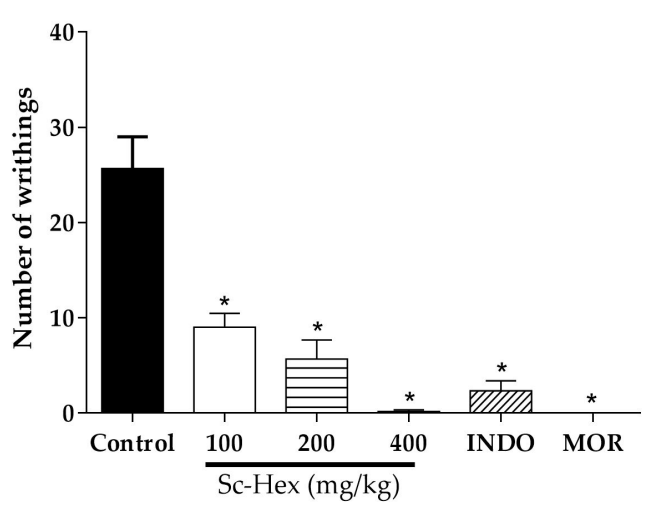

Figure 1. Antinociceptive effect of the hexane fraction from Selaginella convoluta (Sc-Hex), indomethacin (INDO, $20 \mathrm{mg} / \mathrm{kg}$ ) and morphine (MOR, $10 \mathrm{mg} / \mathrm{kg}$ ) on acetic acid-induced writhing in mice. Values are mean \pm S. E.M, $\mathrm{n}=6,{ }^{*} \mathrm{p}<0.05$ significantly different from control (ANOVA followed by Dunnett's test).

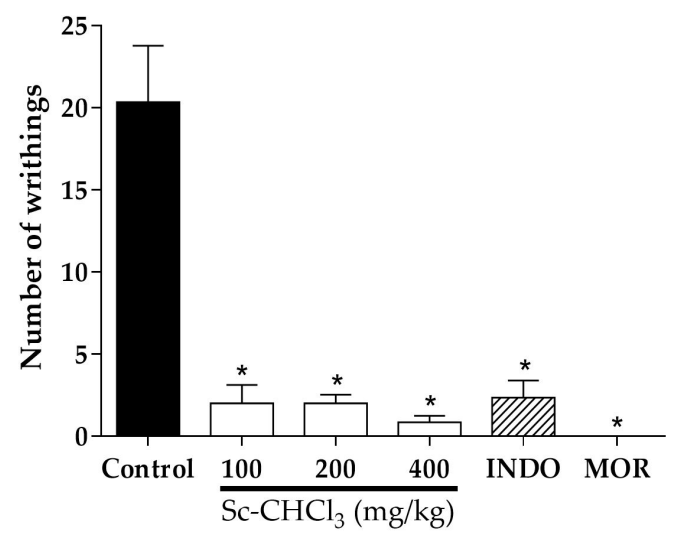

Figure 2. Antinociceptive effect of the chloroform fraction from Selaginella convoluta $\left(\mathrm{Sc}-\mathrm{CHCl}_{3}\right)$, indomethacin (INDO, $20 \mathrm{mg} / \mathrm{kg}$ ) and morphine (MOR, $10 \mathrm{mg} / \mathrm{kg}$ ) on acetic acid-induced writhing in mice. Values are mean \pm S.E.M, $n=6,{ }^{*} \mathrm{p}<0.05$ significantly different from control (ANOVA followed by Dunnett's test).

First phase

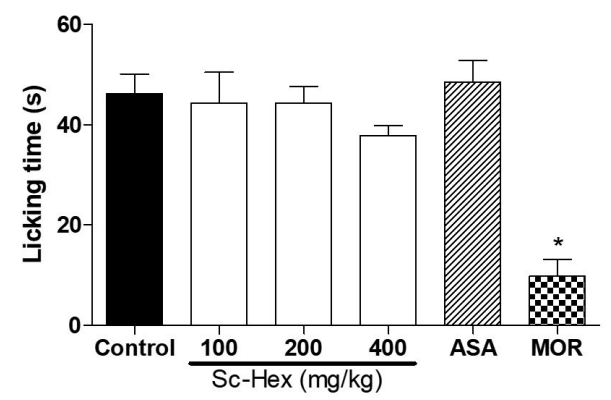

The reference drug acetylsalicylic acid was effective only in the second phase for both fractions $(87.63 \%$ - Sc-Hex and $88.89 \%$ - Sc- $\mathrm{CHCl}_{3}$ ). Morphine decreased the licking time during the two phases.

In the hot plate test, no significant effect was observed for any fraction. The effect of morphine $(10 \mathrm{mg} / \mathrm{kg})$ was significantly higher. Figure 5 and Figure 6 show these results.

Treatment with the $\mathrm{Sc}-\mathrm{CHCl}_{3}$ only at dose of $200 \mathrm{mg} / \mathrm{kg}$ (i.p), caused a significant decrease the volume of the exudates to $1.19 \pm 0.25 \times 10^{6}$ cells $\mathrm{mL} /$ cavity compared with the control group $\left(6.53 \pm 1.40 \times 10^{6}\right.$ cells $\mathrm{mL} /$ cavity) and in total protein extravasations when it was administrated 30 min before carrageenan (Figure 7 and Figure 8). As expected, the reference drug, indomethacin caused a significant inhibition of volume of the exudates to $0.66 \pm 0.14 \mathrm{~mL} /$ cavity.

In the rota rod test, the fractions did not impair motor coordination at $0.5,1$ and $2 \mathrm{~h}$ post administration. Diazepam $(2.5 \mathrm{mg} / \mathrm{kg})$ caused a significant decrease in time that the animals remained on the rota-rod apparatus, compared to the control group (Figure 9 and Figure 10).

\section{Discussion}

The present study reported the evaluation of antinociceptive and anti-inflammatory effects of $S$. convoluta fractions employing various experimental models. Although the plant is widely used in the folk medicine in the semi-arid region of Brazil, only one report about the antinociceptive activity of crude ethanolic extract is recorded in the literature (Sá et al., 2012). Furthermore, current treatments used to fight pain and inflammation are usually insufficient for having severe side effects and limited effectiveness (Bourinet et al., 2005). Therefore, the continuous search for new molecules that are more effective with reduced side adverse is needed.

The antinociceptive activities of fractions, all given intraperitoneally at the doses of 100, 200 and $400 \mathrm{mg} / \mathrm{kg}$, were evaluated using chemical (acetic acid and formalin) and thermal (hot plate test) stimuli. The writhing test has long been used as a screening tool for assessing the

\section{Second phase}

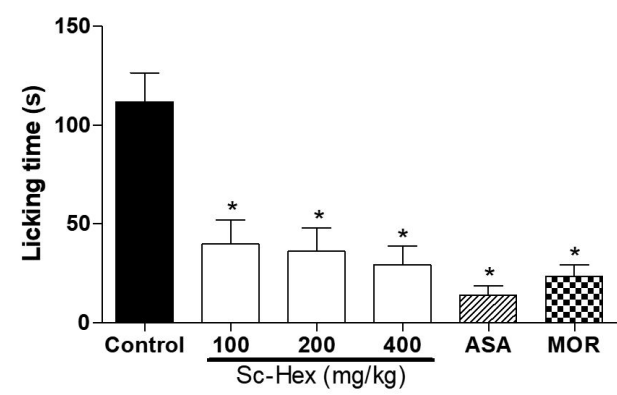

Figure 3. Antinociceptive effect of the hexane fraction of Selaginella convoluta (Sc-Hex), acetylsalicylic acid (ASA, $150 \mathrm{mg} / \mathrm{kg}$ ) and morphine (MOR, $10 \mathrm{mg} / \mathrm{kg}$ ) on formalin (First and second phase). Values are mean \pm S.E.M, $\mathrm{n}=6,{ }^{*} \mathrm{p}<0$. 05 significantly different from control (ANOVA followed by Dunnett's test). 
First phase

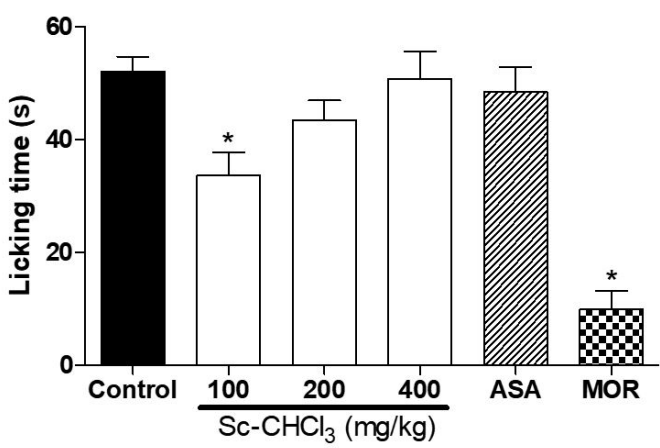

Second phase

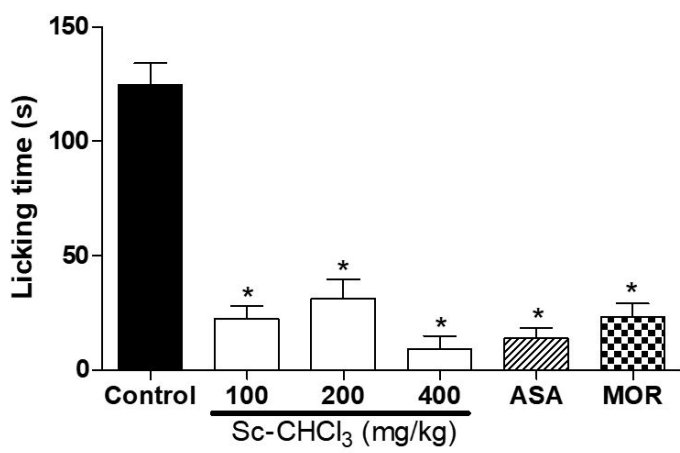

Figure 4. Antinociceptive effect of the chloroform fraction of Selaginella convoluta $\left(\mathrm{Sc}_{-} \mathrm{CHCl}_{3}\right)$, acetylsalicylic acid (ASA, $150 \mathrm{mg} / \mathrm{kg}$ ) and morphine (MOR, $10 \mathrm{mg} / \mathrm{kg}$ ) on formalin (First and second phase). Values are mean \pm S.E.M, $\mathrm{n}=6,{ }^{*} \mathrm{p}<0.05$ significantly different from control (ANOVA followed by Dunnett's test).

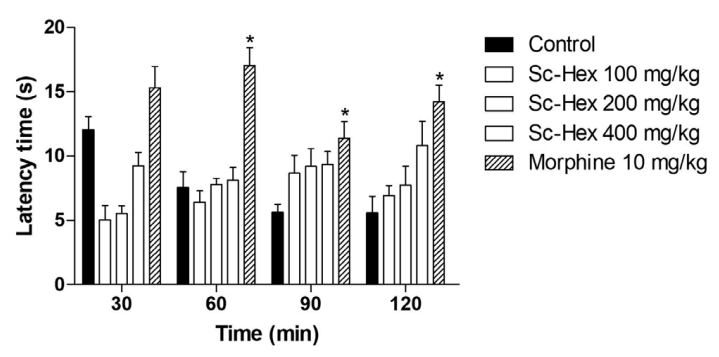

Figure 5. Antinociceptive effect of the hexane fraction of Selaginella convoluta (Sc-Hex) and morphine (MOR, $10 \mathrm{mg} / \mathrm{kg}$ ) on hot plate test. Values are mean \pm S.E.M.; $* p<0.05$, significantly different from control; ANOVA followed Dunnett's.

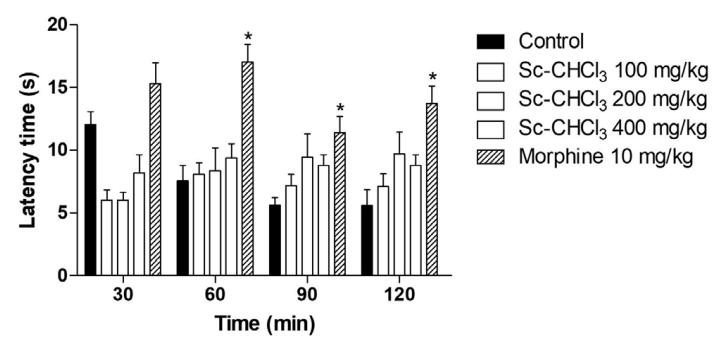

Figure 6. Antinociceptive effect of the chloroform fraction of Selaginella convoluta $\left(\mathrm{Sc}-\mathrm{CHCl}_{3}\right)$ and morphine (MOR, $10 \mathrm{mg} / \mathrm{kg}$ ) on hot plate test. Values are mean \pm S.E.M.; $* p<0.05$, significantly different from control; ANOVA followed Dunnett's.

analgesic properties of new substances (Collier et al., 1968). Intraperitoneal administration of acetic acid induce abdominal writhing and involves the increase in cyclooxygenase (COX), lipoxygenase (LOX), prostaglandins (PGs), histamine, serotonin, bradykinin, substance P, IL- $1 \beta$, IL- 8 , TNF- $\alpha$ in the peritoneal cavity (Farias et al., 2011). These agents provoke a very stereotyped behavior in the mice which is characterized by abdominal contractions, movements of the body as a whole and twisting of dorso-abdominal muscles. However, it is a non-specific method for evaluation of pain (Silva et al., 2010).

$\mathrm{Sc}-\mathrm{Hex}$ and $\mathrm{Sc}-\mathrm{CHCl}_{3}$ significantly reduced the acetic acid-induced writhing in mice. The results support the hypothesis that the fractions have antinociceptive effect on the abdominal constrictions. Additionally, different flavonoids have been found to be antinociceptive and anti-inflammatory agents due to their ability to inhibit the arachidonic acid metabolism (Melo et al., 2008; Havsteen, 2002; Aquila et al., 2009). The presence of flavonoids in the fractions of $S$. convoluta may be responsible for the antinociceptive effect (Macêdo et al., 2018).

In order to extend the studies on the antinociceptive and anti-inflammatory effects, we used the model of nociception induced by formalin. The formalin-induced paw linking test is a model comprising two distinct phases. The first phase (neurogenic pain) occurs about 3 min after the injection, and then after a quiescent period, a second phase (inflammatory pain) between 20 and 30 minutes (Clavelou et al., 1995). The first phase results essentially from chemical stimulation of nociceptive afferent fibers, particularly C-fibers, which can be suppressed by opiates like morphine (Amaral et al., 2007). However, the involvement of substance $\mathrm{P}$ and bradykinin has also been reported. The second phase (inflammatory pain) is induced due to action of inflammatory mediators such as prostaglandins, serotonin and bradykinin in peripheral tissues and functional changes in the dorsal horn of the spinal cord (Cha et al., 2011; Dalal et al., 1999). The Sc-Hex demonstrated that the number of paw licking was significantly reduced only in second phase $(\mathrm{p}<0.05)$ in a dose-dependent manner. However, the $\mathrm{Sc}-\mathrm{CHCl}_{3}$ showed significant effect in both neurogenic and inflammatory pain phases $(\mathrm{p}<0.05)$.

In this experiment, $\mathrm{Sc}-\mathrm{CHCl}_{3}$ decreased the licking time in both phases, but the effect was more significant 


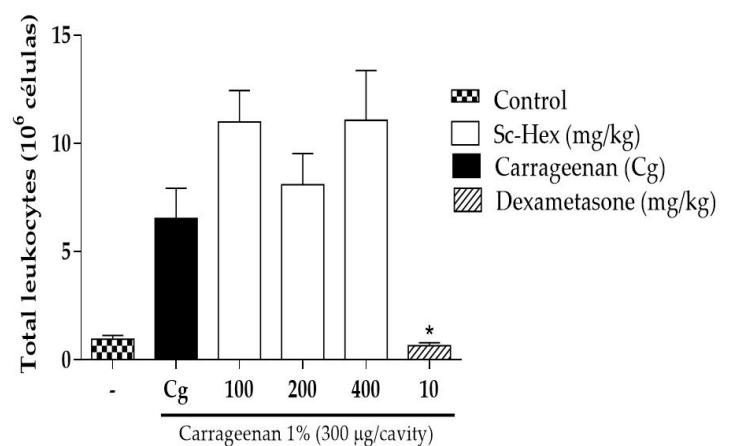

(A)

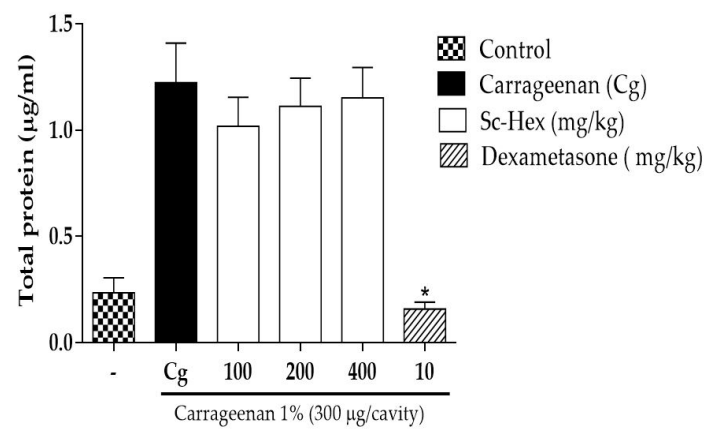

(B)

Figure 7. Effect of the hexane fraction of Selaginella convoluta ( $\mathrm{Sc}-\mathrm{Hex})$ and indomethacin $(10 \mathrm{mg} / \mathrm{kg})$ on total leukocyte (A) and protein extravasation (B) on Pleurisy induced by carrageenan. Values are mean \pm S.E.M.; *p $<0.05$, significantly different from control; ANOVA followed Dunnett's.

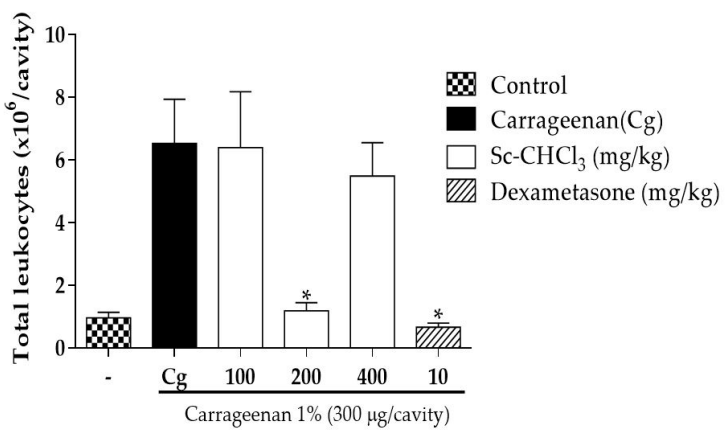

(A)

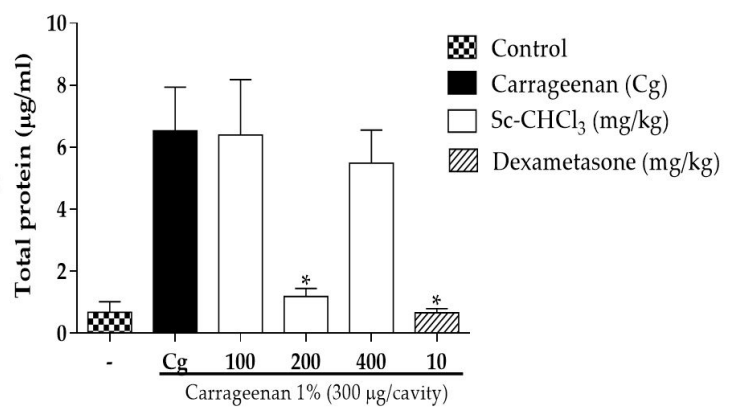

(B)

Figure 8. Effect of the chloroform fraction of Selaginella convoluta $\left(\mathrm{Sc}-\mathrm{CHCl}_{3}\right)$ and indomethacin $(10 \mathrm{mg} / \mathrm{kg})$ on total leukocyte (A) and protein extravasation (B) on Pleurisy induced by carrageenan. Values are mean \pm S.E.M.; *p $<0.05$, significantly different from control; ANOVA followed Dunnett's.

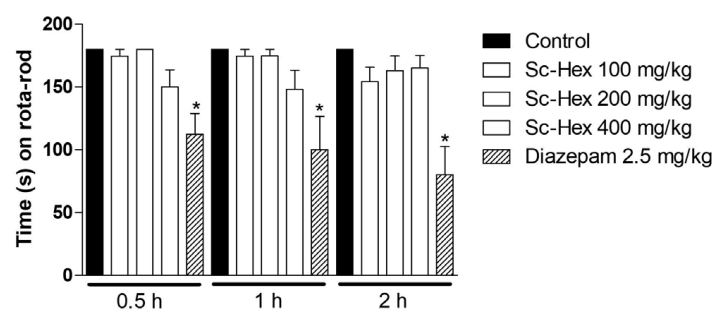

Figure 9. Effect of the hexane fraction of Selaginella convoluta (Sc-Hex) and diazepam $(2.5 \mathrm{mg} / \mathrm{kg})$ on rota-rod test. Values are mean \pm S.E.M.; *p $<0.05$, significantly different from control; ANOVA followed Dunnett's.

in the second phase. The inhibition in both phases is characteristic of drugs that act centrally, and indicates a possible interaction with opioid receptors. Opioid analgesics seem to be antinociceptive for both phases, although the first is more sensitive to these substances. In contrast, non-steroidal anti-inflammatory drugs such as indomethacin and acetylsalicylic acid seem to suppress only the second phase (Hunskaar and Hole, 1987).

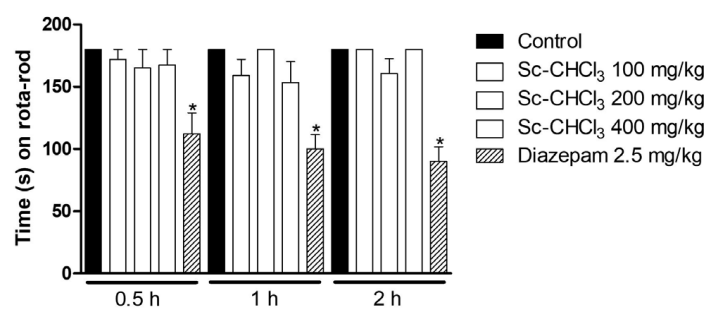

Figure 10. Effect of the chloroformic fraction of Selaginella convoluta $\left(\mathrm{Sc}_{-} \mathrm{CHCl}_{3}\right)$ and diazepam $(2,5 \mathrm{mg} / \mathrm{kg})$ on rota-rod test. Values are mean \pm S.E.M.; $* p<0.05$, significantly different from control; ANOVA followed Dunnett's.

The results obtained in the acetic acid-induced writhing test and formalin test were similar to those observed by Sá et al. (2012) when evaluating the crude ethanolic extract from $S$. convoluta. They related that the crude ethanolic extract also exhibited reduced writhing and decreased the paw licking time in mice during the first phase of the formalin test as well as during the second phase of the test, but the reduction was most significant in the second phase. 
In order to confirm the antinociceptive activity and to investigate the involvement of the central mechanisms of the effects of the fractions, the hot plate test was used. In this test, the intraperitoneal administration of fractions didn't affect mice's reactivity at the thermal stimulus, demonstrating that the antinociceptive effect in the abdominal constriction (writhing) test probably do not involve central mechanisms. In contrast, in the study realized by Sá et al. (2012) treatment at doses of 200 and $400 \mathrm{mg} / \mathrm{kg}$ of the crude ethanolic extract increased the latency time in the hot plate test after 60 and 90 minutes, respectively.

To evaluate the anti-inflammatory effect of the fractions, the model of carrageenan-induced pleurisy in mice was used. The pleurisy induced by phlogistic agents is a widely accepted model for the evaluation of the anti-inflammatory effect of compounds from plants.

Inflammation is a protective process that is essential for the preservation of the integrity of the organism in the event of chemical, physical and infectious damage. Often, the inflammatory response to severe lesions erroneously damages normal tissue (Farias et al., 2011).

Recruitment of cells to inflammatory sites is dependent on the release of vasoactive and chemotactic factors that increase the local blood flow and microvascular permeability and promote the migration of leukocytes from the intravascular space into the tissues (Farias et al., 2011). In this study, intrapleural injection of carrageenan induced an acute inflammatory reaction, characterized by marked accumulation of exudates rich in protein and intense migration of polymorphonuclear in the pleural cavities. Treatment of the animals with $200 \mathrm{mg} / \mathrm{kg}$ of Sc- $\mathrm{CHCl}_{3}$ attenuated the number of total leukocytes and total protein concentration in the exudate after carrageenan stimulus (Zhao et al., 2007). However, this result is not sufficient to affirm that the plant has anti-inflammatory activity, because this effect was observed only in one dose of fractions.

Finally, to assess whether extracts produces a loss of motor coordination in animals, the rota-rod test was performed. Motor coordination tests are used in the screening of drugs with possible myorelaxant/neurotoxic effect, since they are tests that are capable to detect the muscle relaxant activity and motor incoordination of agents with pharmacological properties, as is the case with many analgesics (Pultrini et al., 2006; Baggio et al., 2012). The result revealed that the extracts did not produce changes in motor coordination of treated animals.

In conclusion, this study indicates that the hexane and chloroform fractions of Selaginella convoluta exhibit antinociceptive activity. Our results support previous claims of its traditional use. The mechanism of action of these extracts showed linked with possible activation of nociceptive peripheral pathway. In addition, we have demonstrated that the extracts from $S$. convoluta have not any anti-inflammatory effect in the pleurisy model induced by carrageenan. Further studies are necessary to identify the biologically active constituents and to define the underlying of molecular mechanisms of the inhibitory effects of these fractions.

\section{Acknowledgements}

The authors are grateful to Brazilian agencies CNPq, FAPEAL and FACEPE for financial support.

\section{References}

ADEDAPO, A.A., SOFIDIYA, M.O., MAPHOSA, V., MOYO, B., MASIKA, P. and AFOLAYAN, A.J., 2008. Anti-inflammatory and analgesic activities of the aqueous extract of Cussonia paniculata stem bark. Records of Natural Products, vol. 2, pp. 46-53.

AGRA, M.F., BARACHO, G.S., NURIT, K., BASÍLIO, I.J.L. and COELHO, V.P., 2007. Medicinal and poisonous diversity of the flora of "Cariri Paraibano", Brazil. Journal of Ethnopharmacology, vol. 111, no. 2, pp. 383-395. http://dx.doi. org/10.1016/j.jep.2006.12.007. PMid:17236731.

ALBUQUERQUE, U.P., MEDEIROS, P.M., ALMEIDA, A.L.S., MONTEIRO, J.M., LINS NETO, E.M.F., MELO, J.G. and SANTOS, J.P., 2007. Medicinal plants of the Caatinga (semiarid) vegetation of NE Brazil: a quantitative approach. Journal of Ethnopharmacology, vol. 114, no. 3, pp. 325-354. http://dx.doi. org/10.1016/j.jep.2007.08.017. PMid:17900836.

ALMEIDA, J.R., LIMA, J.T., OLIVEIRA, H.R., OLIVEIRA, M.R., MEIRA, P.R., LÚCIO, A.S., BARBOSA FILHO, J.M. and QUINTANS JÚNIOR, L.J., 2011. Antinociceptive activity of discretamine isolated from Duguetia moricandiana. Natural Product Research, vol. 25, no. 20, pp. 1908-1915. http://dx.doi. org/10.1080/14786419.2010.491227. PMid:21656417.

ALMEIDA, J.R.G.S., MORAES, A.C.A., RIBEIRO, R.L., GOIS, R.M.O. and QUINTANS-JUNIOR, L.J., 2005. Plantas medicinais comercializadas por raizeiros no Vale do São Francisco. In: Anais da $1^{a}$ Reunião Regional da Sociedade Brasileira de Plantas Medicinais, 2005, Fortaleza, CE. Fortaleza: UFC.

ALMEIDA, J.R.G.S., SÁ, P.G.S., MACEDO, L.A.R.O., SIQUEIRA-FILHO, J.A., OLIVEIRA, V.R. and BARBOSAFILHO, J.M., 2013. Phytochemistry of the genus Selaginella (Selaginellaceae). Journal of Medicinal Plants Research, vol. 7, pp. 1858-1868.

AMARAL, J.F., SILVA, M.I.G., TEIXEIRA NETO, P.F., MOURA, B.A., MELO, C.T.V., ARAÚJO, F.L.O., SOUSA, D.P., VASCONCELOS, P.F., VASCONCELOS, S.M. and SOUSA, F.C.F., 2007. Antinociceptive effect of the monoterpene R-(-)limonene in mice. Biological \& Pharmaceutical Bulletin, vol. 30, no. 7, pp. 1217-1220. http://dx.doi.org/10.1248/bpb.30.1217. PMid:17603156.

AQUILA, S., GINER, R.M., RECIO, M.C., SPEGAZZINI, E.D. and RÍOS, J.L., 2009. Anti-inflammatory activity of flavonoids from Cayaponia tayuya roots. Journal of Ethnopharmacology, vol. 121, no. 2, pp. 333-337. http://dx.doi.org/10.1016/j.jep.2008.11.002. PMid:19041703.

BAGGIO, C.H., FREITAS, C.S., MARCON, R., WERNER, M.F., RAE, G.A., SMIDERLE, F.R., SASSAKI, G.L., IACOMINI, M., MARQUES, M.C. and SANTOS, A.R., 2012. Antinociception of $\beta-D$-glucan from Pleurotus pulmonarius is possibly related to protein kinase $\mathrm{C}$ inhibition. International Journal of Biological Macromolecules, vol. 50, no. 3, pp. 872-877. http://dx.doi. org/10.1016/j.ijbiomac.2011.10.023. PMid:22085751.

BASSO, L.A., SILVA, L.H.P., FETT-NETO, A.G., AZEVEDO JUNIOR, W.F., MOREIRA, Í.S., PALMA, M.S., CALIXTO, J.B., ASTOLFI FILHO, S., SANTOS, R.R., SOARES, M.B.P. 
and SANTOS, D.S., 2005. The use of biodiversity as source of new chemical entities against defined molecular targets for treatment of malaria, tuberculosis, and T-cell mediated diseases - A Review. Memorias do Instituto Oswaldo Cruz, vol. 100, no. 6, pp. 475-506. http://dx.doi.org/10.1590/S0074-02762005000600001. PMid:16302058.

BOURINET, E., ALLOUI, A., MONTEIL, A., BARRERE, C., COUETTE, B., POIROT, O., PAGES, A., MCRORY, J., SNUTCH, T.P., ESCHALIER, A. and NARGEOT, J., 2005. Silencing of the Cav 3.2 T-type calcium channel gene in sensory neurons demonstrates it is major role in nociception. The EMBO Journal, vol. 24, no. 2, pp. 315-324. http://dx.doi.org/10.1038/ sj.emboj.7600515. PMid:15616581.

CARVALHO, A.A., GALDINO, P.M., NASCIMENTO, M.V., KATO, M.J., VALADARES, M.C., CUNHA, L.C. and COSTA, E.A., 2010. Antinociceptive and anti-inflammatory activities of grandisin extracted from Virola surinamensis. Phytotherapy Research, vol. 24, no. 1, pp. 113-118. http://dx.doi.org/10.1002/ ptr.2882. PMid:19468987.

CHA, D.S., EUN, J.S. and JEON, H., 2011. Anti-inflammatory and antinociceptive properties of the leaves of Eriobotrya japonica. Journal of Ethnopharmacology, vol. 134, no. 2, pp. 305-312. http://dx.doi.org/10.1016/j.jep.2010.12.017. PMid:21182921.

CHEN, J.J., DUH, C.Y. and CHEN, J.F., 2005. New cytotoxic biflavonoids from Selaginella delicatula. Planta Medica, vol. 71, no. 7, pp. 659-665. http://dx.doi.org/10.1055/s-2005-871273. PMid:16041653.

CHIKMAWATI, T., SETYAWAN, A.D. and MIFTAHUDIN, 2008. Phytochemical content of Selaginella plant extracts on the island of Java. In: Proceedings of the 8th Seminary and Congress of Indonesian Association of Plant Taxonomy (PTTI), 2008, Bogor, Indonesia. Indonesia: Cibinong Science Center.

CLAVELOU, P., DALLEL, R., ORLIAGUET, T., WODA, A. and RABOISSON, P., 1995. The orofacial formalin test in rats: effects of different formalin concentrations. Pain, vol. 62, no. 3, pp. 295-301. http://dx.doi.org/10.1016/0304-3959(94)00273-H. PMid:8657429.

COLLIER, H.O., DINNEEN, L.C., JOHNSON, C.A. and SCHNEIDER, C., 1968. Abdominal contrition response and its suppression by analgesic drugs in mouse. British Journal of Pharmacology and Chemotherapy, vol. 32, no. 2, pp. 295-310. http:// dx.doi.org/10.1111/j.1476-5381.1968.tb00973.x. PMid:4230818.

DALAL, A., TATA, M., ALLEGRE, G., GEKIERE, F., BONS, N. and ALBE-FESSARD, D., 1999. Spontaneous activity of rat dorsal horn cells in spinal segments of sciatic projection following trisections of sciatic nerve or of corresponding dorsal roots. Neuroscience, vol. 94, no. 1, pp. 217-228. http://dx.doi. org/10.1016/S0306-4522(99)00328-0. PMid:10613512.

FARIAS, J.A.C., FERRO, J.N.S., SILVA, J.P., AGRA, I.K.R., OLIVEIRA, F.M., CANDEA, A.L.P., FERRARIS, F.K., CONTE, F.P., HENRIQUES, M.G.M.O., CONSERVA, L.M. and BARRETO, E.O., 2011. Modulation of Inflammatory processes by leaves extract from Clusia nemorosa both in vitro and in vivo animal models. Inflammation, vol. 13, no. 2, pp. 764-771. http:// dx.doi.org/10.1007/s10753-011-9372-y. PMid:21842373.

GAMBHIR, S.S., GOEL, R.K. and DASGUPTA, G., 1987. Anti-inflammatory and antiulcerogenic activity of amentoflavone. The Indian Journal of Medical Research, vol. 85, pp. 689-693. PMid:2824354.
GIORGETTI, M., NEGRI, G. and RODRIGUES, E., 2007. Brazilian plants with possible action on the central nervous system: a study of historical sources from the 16th to 19th century. Journal of Ethnopharmacology, vol. 109, no. 2, pp. 338-347. http://dx.doi. org/10.1016/j.jep.2006.08.003. PMid:16982166.

HAVSTEEN, B.H., 2002. The biochemistry and medical significance of the flavonoids. Pharmacology \& Therapeutics, vol. 96, no. 2-3, pp. 67-202. http://dx.doi.org/10.1016/S01637258(02)00298-X. PMid:12453566.

HUNSKAAR, S. and HOLE, K., 1987. The formalin test in mice: dissociation between inflammatory and non-inflammatory pain. Pain, vol. 30, no. 1, pp. 103-114. http://dx.doi.org/10.1016/03043959(87)90088-1. PMid:3614974.

JEELANI, S.M., RATHER, G.A., SHARMA, A. and LATTOO, S., 2017. In perspective: potential medicinal plant resources of Kashmir Himalayas, their domestication and cultivation for commercial exploitation. Journal of Applied Research on Medicinal and Aromatic Plants, vol. 2017, pp. 1-16.

JUDD, W.S., CAMPBELL, C.S., KELLOG, E.A. and STEVENS, P.F., 1999. Plant systematics: a phylogenetic approach. Sunderland: Sinauer Associates.

JUNG, H.J., SUNG, W.S., YEO, S.H., KIM, H.S., LEE, I.S., WOO, E.R. and LEE, D.G., 2006. Antifungal effect of amentoflavone derived from Selaginella tamariscina. Archives of Pharmacal Research, vol. 29, no. 9, pp. 746-751. http://dx.doi.org/10.1007/ BF02974074. PMid:17024847.

KIM, H.K., SON, K.H., CHANG, H.W., KANG, S.S. and KIM, H.P., 1998. Amentoflavone, a plant biflavone: a new potential anti-inflammatory agent. Archives of Pharmacal Research, vol. 21, no. 4, pp. 406-410. http://dx.doi.org/10.1007/BF02974634. PMid:9875467.

KOSTER, R., ANDERSON, M. and BEER, E.J., 1959. Acetic acid for analgesic screening. Federation Proceedings, vol. 18, pp. 412-418.

KUMARA, N.K.V.M.R., 2001. Identification of strategies to improve research on medicinal plants used in Sri Lanka. In: Proceedings of the WHO Symposium, 2001, Sri Lanka. Sri Lanka: University of Ruhuna.

KUNERT, O., SWAMY, R.C., KAISER, M., PRESSER, A., BUZZI, S., APPA-RAO, A.V.N. and SCHÜHLY, W., 2008. Antiplasmodial and leishmanicidal activity of biflavonoids from Indian Selaginella bryopteris. Phytochemistry Letters, vol. 1, no. 4, pp. 171-174. http://dx.doi.org/10.1016/j.phytol.2008.09.003.

LEE, J., CHOI, Y., WOO, E.R. and LEE, D.G., 2009a. Antibacterial and synergistic activity of isocryptomerin isolated from Selaginella tamariscina. Journal of Microbiology and Biotechnology, vol. 19, no. 2, pp. 204-207. http://dx.doi.org/10.4014/jmb.0810.566. PMid:19307771

LEE, J., CHOI, Y., WOO, E.R. and LEE, D.G., 2009 b. Isocryptomerin, a novel membrane-active antifungal compound from Selaginella tamariscina. Biochemical and Biophysical Research Communications, vol. 379, no. 3, pp. 676-680. http:// dx.doi.org/10.1016/j.bbrc.2008.12.030. PMid:19101515.

LIMA-SARAIVA, S.R.G., SARAIVA, H.C.C., SILVA, J.C., LIMA, J.T., SIQUEIRA FILHO, J.A., DAMASCENO, P.K.F., BRANCO, C.R.C., BRANCO, A., AMORIM, E.L.C. and ALMEIDA, J.R.G.S., 2012. Antinociceptive effect of the ethanolic extract of Neoglaziovia variegata (Bromeliaceae) in 
mice. Journal of Medicinal Plants Research, vol. 6, no. 40, pp. 5330-5336. http://dx.doi.org/10.5897/JMPR12.122.

LIN, Y.-M., FLAVIN, M.T., SCHURE, R., CHEN, F.-C., SIDWELL, R., BARNARD, D.I., HUFFMANN, J.H. and KERN, E.R., 1999. Antiviral activities of bioflavonoids. Planta Medica, vol. 65, no. 2, pp. 120-125. http://dx.doi.org/10.1055/s-1999-13971. PMid:10193201.

MACÊDO, L.A.R.D.O., OLIVEIRA JÚNIOR, R.G.D., SOUZA, G.R., DE OLIVEIRA, A.P., DE LAVOR, E.M., SILVA, M.G., PACHECO, A.G.M., MENEZES, I.R.A., COUTINHO, H.D.M., PESSOA, C.O., DA COSTA, M.P. and ALMEIDA, J.R.G.S., 2018. Chemical composition, antioxidant and antibacterial activities and evaluation of cytotoxicity of the fractions obtained from Selaginella convoluta (Arn.) Spring (Selaginellaceae). Biotechnology, Biotechnological Equipment, vol. 2018, pp. 1-7.

MELO, M.G.D., ARAÚJO, A.A.S., ROCHA, C.P.L., ALMEIDA, E.M.S.A., SIQUEIRA, R.S., BONJARDIM, L.R. and QUINTANSJÚNIOR, L.J., 2008. Purification, physicochemical properties, thermal analysis and antinociceptive effect of atranorin extracted from Cladina kalbii. Biology Pharmacollogy Bulletins, vol. 31, no. 10, pp. 1977-1980. http://dx.doi.org/10.1248/bpb.31.1977. PMid:18827367.

MENICHINI, F., CONFORTI, F., RIGANO, D., FORMISANO, C., PIOZZI, F. and SENATORE, F., 2009. Phytochemical composition, anti-inflammatory and antitumor activities of four Teucrium essential oils from Greece. Food Chemistry, vol. 115, no. 2, pp. 679-686. http://dx.doi.org/10.1016/j.foodchem.2008.12.067.

NAHAR, L., NASRIN, F., ZAHAN, R. and MOSADDIK, M.A., 2013. Anti-nociceptive and anti-inflammatory activities of Wrightia arborea. Pakistan Journal of Biological Sciences, vol. 16, no. 10, pp. 485-490. http://dx.doi.org/10.3923/pjbs.2013.485.490. PMid:24498815.

NEWMAN, D.J. and CRAGG, G.M., 2016. Natural products as sources of new drugs from 1981 to 2014. Journal of Natural Products, vol. 79, no. 3, pp. 629-661. http://dx.doi.org/10.1021/ acs.jnatprod.5b01055. PMid:26852623.

PANDEY, S., KHAN, A.A., SHANKAR, K. and SINGH, N., 1993. An experimental study on the anti-stress and antioxidant activity of Selaginella bryopteris. Journal of Biological Chemical Research, vol. 12, pp. 128-129.

PULTRINI, A.M., GALINDO, L.A. and COSTA, M., 2006. Effects of the essential oil from Citrus aurantium L. in experimental anxiety models in mice. Life Sciences, vol. 78, no. 15, pp. 17201725. http://dx.doi.org/10.1016/j.lfs.2005.08.004. PMid:16253279.

RATES, S.M.K., 2001. Plants as source of drugs. Toxicon, vol. 39, no. 5, pp. 603-613. http://dx.doi.org/10.1016/S00410101(00)00154-9. PMid:11072038.

SA, P.G.S., NUNES, X.P., LIMA, J.T., SIQUEIRA-FILHO, J.A., FONTANA, A.P., QUINTANS, J.S.S., QUINTANS-JUNIOR, L.J., DAMASCENO, P.K.F., BRANCO, C.R.C., BRANCO, A. and ALMEIDA, J.R.G.S., 2012. Antinociceptive effect of ethanolic extract of Selaginella convoluta in mice. BMC Complementary and Alternative Medicine, vol. 12, pp. 1-7. PMid:23082856.
SANTOS, R.V.H., LEÔNCIO, M.P. and AFIATPOUR, P., 1994. Efeitos farmacológicos e ação diurética do extrato hidroalcoólico de Selaginella convoluta spring. In: Anais do XIII Simpósio Brasileiro de Plantas Medicinais, 1994, Fortaleza. Fortaleza: UFC, pp. 40.

SILVA, G.L., CHAI, H., GUPTA, M.P., FARNSWORTH, N.R., CORDELL, G.A., PEZZUTO, J.M., BEECHER, C.W. and KINGHORN, A.D., 1995. Cytotoxic biflavonoids from Selaginella willdenowii. Phytochemistry, vol. 40, no. 1, pp. 129-134. http:// dx.doi.org/10.1016/0031-9422(95)00212-P. PMid:7546547.

SILVA, J.P., RODARTE, R.S., CALHEIROS, A.S., SOUZA, C.Z., AMENDOEIRA, F.C., MARTINS, M.A., SILVA, P.M.R., FRUTUOSO, V.S. and BARRETO, E., 2010. Antinociceptive activity of aqueous extract of Bowdichia virgilioides in mice. Journal of Medicinal Food, vol. 13, no. 2, pp. 348-351. http:// dx.doi.org/10.1089/jmf.2009.0099. PMid:20170383.

SOBOTA, R., SZWED, M., KASZA, A., BUGNO, M. and KORDULA, T., 2000. Parthenolide inhibits activation of signal transducers and activators of transcription (STATs) induced by cytokines of the IL-6 family. Biochemical and Biophysical Research Communications, vol. 267, no. 1, pp. 329-333. http:// dx.doi.org/10.1006/bbrc.1999.1948. PMid:10623619.

STAUFFER, C.E., 1975. A linear standard curve for the FolinLowry determination of protein. Analytical Biochemistry, vol. 69, no. 2, pp. 646-648. http://dx.doi.org/10.1016/0003-2697(75)901724. PMid: 1217730 .

SUBRAMONIAM, A., GAYATHRI, V. and ASHA, V.V., 2005. Preliminary studies on the immunomodulatory and antioxidant properties of Selaginella species. Indian Journal of Pharmacology, vol. 37 , no. 6 , pp. 381-385. http://dx.doi.org/10.4103/02537613.19075 .

TRYON, R.M. and TRYON, A.F., 1982. Ferns and allied plants. Cambridge: Harvard University. http://dx.doi.org/10.1007/9781-4613-8162-4.

VIANA, G.S.B., DO VALE, T.G., RAO, V.S.N. and MATOS, F.J.A., 1998. Analgesic and anti-inflammatory effects of two chemotypes of Lipia alba: a comparative study. Pharmacentical Biology, vol. 36, no. 5, pp. 347-351. http://dx.doi.org/10.1076/ phbi.36.5.347.4646.

WAGNER, H. and BLADT, S. (1996). Plant drug analysis: a thin layer chromatography atlas. 2nd ed. Berlin: Springer-Verlag.

WOO, E.R., POKHAREL, Y.R., YANG, J.W., LEE, S.Y. and KANG, K.W., 2006. Inhibition of nuclear factor- $\kappa B$ activation by 2', 8"-biapigenin. Biological \& Pharmaceutical Bulletin, vol. 29, no. 5, pp. 976-980. http://dx.doi.org/10.1248/bpb.29.976. PMid:16651730.

ZHAO, L., TAO, J.Y., ZHANG, S.L., PANG, R., JIN, F., DONG, J.H. and GUO, Y.J., 2007. Inner anti-inflammatory mechanisms of petroleum ether extract from Melilotus suaveolens Ledeb. Inflammation, vol. 30, no. 6, pp. 213-223. http://dx.doi. org/10.1007/s10753-007-9039-x. PMid:17763929. 